Western North American Naturalist 67(3), ㅇ 2007, pp. 338-346

\title{
POLYMORPHIC INDIAN RICEGRASS POPULATIONS RESULT FROM OVERLAPPING WAVES OF MIGRATION
}

\author{
T.A. Jones ${ }^{1,2}$, M.G. Redinbaugh ${ }^{1,3}$, S.R. Larson ${ }^{1}$, Y. Zhang ${ }^{1}$, and B.D. Dow ${ }^{1,4}$
}

\begin{abstract}
Indian ricegrass (Achnatherum hymenoides [Roem. \& Schult.] Barkworth) is a rangeland species native to western North America with populations that may exhibit distinct seed-size morphs borne on separate plants. These morphs are often associated with very different levels of seed dormancy. We compared RAPD profiles of the relatively infrequent and highly dormant jumbo seed morph to its more germinable small or large (non-jumbo) companion seed morphs collected from 9 sites where they were sympatric. Jumbo seed accessions from 9 additional sites that did not exhibit seed polymorphism were included to better sample this seed morph across the species' range. Sympatric seed morphs were consistently distinguishable by their RAPD profiles, and sympatric seed morphs were no more likely to cluster together than nonsympatric seed morphs. The ability of sympatric seed morphs to maintain their genetic identity is compatible with the hypothesis of a predominately autogamous breeding system. Furthermore, these data support the hypothesis that local polymorphic populations result from overlapping waves of migration with distinct geographical origins. The jumbo seed morphs exhibited moderate correlation between genetic distance and geographic distance, but the non-jumbo seed morphs exhibited no such correlation. Jumbo seed morphs that were collected at or east of the Continental Divide in New Mexico and Colorado are more genetically homogeneous than those west of the Continental Divide, and non-jumbo seed morphs from the east are more genetically variable than jumbo seed morphs from the same locations. This suggests that gene flow eastward across the Rocky Mountains has been more frequent for the non-jumbo seed morphs than for the jumbo seed morphs.
\end{abstract}

Key words: seed polymorphism, migration, seed dormancy.

Indian ricegrass (Achnatherum hymenoides [Roem. \& Schult.] Barkworth) is a native rangeland bunchgrass of the Stipeae tribe with a distribution extending from the Nebraska sandhills to the eastern slopes of the Cascade and Sierra Nevada ranges and from Mexico to Canada at elevations up to $3000 \mathrm{~m}$ (Booth et al. 1980). Early reports of seed-size polymorphism were made by Huntamer (1934) and Stoddart and Wilkinson (1938). These seed morphs are borne on different plants, and the trait is heritable (Huntamer 1934). Jones and Nielson (1996) conservatively estimated that $21 \%$ of 318 populations sampled exhibited multiple discrete seed-size morphs (e.g., small, large, or jumbo; Fig. 1). Of 384 seed morphs examined from the 318 populations, about $72 \%$ were small, $22 \%$ were large, and $6 \%$ were jumbo. Of 11 regions sampled, seed polymorphism was most frequent in the southeastern Great Basin (34\% of 91 accessions). The jumbo seed morph was most frequent in the southwestern Great Plains (33\% of 6 morphs).

Seed dormancy is a major component of the germination ecology of Indian ricegrass (Jones 1990). This seed dormancy is partly mechanical, controlled by the thickness of the lemma and palea (collectively referred to as the "hull"), and partly physiological (Huntamer 1934). Toole (1940) and Fendall (1966) showed that the hull excludes $\mathrm{O}_{2}$, which is necessary for triggering germination. Zemetra and Cuany (1984) reported variation for lemma thickness among accessions. Across a wide range of accessions grown in 2 common gardens, Zemetra (1979) found a negative correlation between lemma thickness and germination percentage. Jones and Nielson (1999) found that seed mass, seed dormancy, and lemma and palea thicknesses were positively correlated among sympatric small, large, and jumbo seed morphs of T-593 (Star Lake, NM) Indian ricegrass (Fig. 1). These results suggest that (1) seed

${ }^{1}$ USDA Agricultural Research Service, Forage and Range Research Laboratory; Department of Forest, Range, and Wildlife Sciences and Department of Plants, Soils, and Biometeorology, Utah State University, Logan, UT 84322-6300.

2E-mail: tomjones@cc.usu.edu

${ }^{3}$ USDA Agricultural Research Service, Corn and Soybean Research, OARDC, 1680 Madison Ave., Wooster, OH 44691-4096.

${ }^{4}$ Former USDA Agricultural Research Service research associate, Utah State University, Logan, UT 84322-6300. 


\section{$\because 1010101110$}

Fig. 1. Jumbo (T-593j, left), large (T-593g, center), and small (T-593s, right) seed morphs of T-593 Indian ricegrass (Star Lake, NM).

dormancy is associated with hull thickness, in agreement with Huntamer's (1934) observation, and (2) the positive relationship between seed size and seed dormancy may be partly due to a positive relationship between hull thickness and seed dormancy.

Indian ricegrass seed morphs typically differ in seed dormancy (Jones and Nielson 1999) as well as vegetative morphological characters (T.A. Jones personal observation). Seed dormancy is generally greater for large seed morphs than for small seed morphs (Huntamer 1934, Stoddart and Wilkinson 1938, Toole 1940, Young and Evans 1984). Relative seed morph frequencies at a site could fluctuate over time based on how recent environmental conditions have differentially favored seed morphs with prolonged versus shortened dormancy.

Seeds of 3 Indian ricegrass cultivars, Paloma (origin in Pueblo, CO), Nezpar (origin in Whitebird, ID), and Rimrock (origin in Billings, MT), are currently commercially available for rangeland rehabilitation and restoration efforts. Paloma has large seeds, and Nezpar and Rimrock have small seeds. Seeds are raised by individual growers or seed companies and typically must be certified for genetic purity as a condition of purchase by federal or state agencies. Seed certification (Jones 2005) is granted or denied by an official certifying agency according to standards for Indian ricegrass adopted by the Association of Official Seed Certifying Agencies (AOSCA 2005). Knowledge of a species' mating system (degree of outcrossing), determined by research, is important in development of meaningful standards to ensure that isolation distance between seed fields of the same or closely related species is adequate to preclude pollen contamination.

Little information regarding mating system is available within the Stipeae grass tribe (M.E. Barkworth personal communication), though the genetic data of Larson et al. (2001) strongly support autogamy for purple needlegrass (Nassella pulchra [Hitchc.] Barkworth). A sizable literature on naturally occurring hybrids of Indian ricegrass with other species of the Stipeae tribe (Johnson and Rogler 1943, Johnson 1945, 1960, 1962, 1963, Nielson and Rogler 1952, Weber 1957) has given some the impression that Indian ricegrass is predominately allogamous. Nevertheless, Jones and Nielson (1989) found no self-incompatibility in this species.

Our objectives were to use RAPD markers to (1) characterize genetic similarity of sympatric seed morphs, and (2) compare genetic variation across locations of jumbo versus nonjumbo seed morphs.

\section{Methods}

We analyzed seeds of the jumbo seed morph from 18 collection locations (accessions) in Arizona, Colorado, Nevada, New Mexico, and Utah (Table 1, Fig. 2). Seeds were collected in bulk from 25 or more individual plants at each site. Nine of the locations were monomorphic for the jumbo seed morph, and 9 were polymorphic. Of these 9 polymorphic sites, 7 were dimorphic with 1 non-jumbo seed morph (either large or small), and 2 were trimorphic with 2 non-jumbo seed morphs (large and small). Thus, we examined a total of 18 jumbo and 11 sympatric non-jumbo seed morphs.

Care was taken to avoid sites with evidence of seeding; therefore, we believe all of our materials to be naturally occurring on their respective sites. None of the 3 cultivars possesses jumbo seeds, so it is unlikely that the geographical distribution of jumbo seeds has been anthropogenically influenced. The 3 large-seeded accessions, the same morph as Paloma, did not cluster near one another in the dendrogram (Fig. 3), so there was no evidence that more than 1 of them might be Paloma. With 1 exception (T-804s from Patterson Wash, NV, and T-848s from Leamington, UT), the 8 small-seeded accessions, the same 
TABLE 1. Locations of 18 sites in 6 western states where 18 jumbo and 11 non-jumbo seed morphs were collected.

\begin{tabular}{|c|c|c|c|}
\hline Location & Jumbo & Large & Small \\
\hline \multicolumn{4}{|l|}{1 seed morph per site } \\
\hline 1. Cane Beds, AZ & $\mathrm{T}-752 \mathrm{j}$ & - & - \\
\hline 2. Mt. Trumbull, AZ & $\mathrm{T}-755 \mathrm{j}$ & - & - \\
\hline 3. Abbott, NM & $\mathrm{T}-866 \mathrm{j}$ & - & - \\
\hline 4. Cuba, NM & $\mathrm{T}-591 \mathrm{j}$ & - & - \\
\hline 5. Calf Creek, UT & $\mathrm{T}-717 \mathrm{j}$ & - & - \\
\hline 6. Dugway, UT & $\mathrm{T}-854 \mathrm{j}$ & - & - \\
\hline 7. Escalante, UT & $\mathrm{T}-715 \mathrm{j}$ & - & - \\
\hline 8. Iosepa, UT & $\mathrm{T}-852 \mathrm{j}$ & - & - \\
\hline 9. NE Kanab, UT & $\mathrm{T}-724 \mathrm{j}$ & - & - \\
\hline \multicolumn{4}{|l|}{2 seed morphs per site } \\
\hline 10. Cameron, AZ & $\mathrm{T}-740 \mathrm{j}$ & - & $\mathrm{T}-740 \mathrm{~s}$ \\
\hline 11. Hawley, CO & $\mathrm{T}-877 \mathrm{j}$ & $\mathrm{T}-877 \mathrm{~g}$ & - \\
\hline 12. Montello, NV & $\mathrm{T}-27 \mathrm{j}$ & - & $\mathrm{T}-26 \mathrm{~s}$ \\
\hline 13. Patterson Wash, NV & $\mathrm{T}-804 \mathrm{j}$ & - & $\mathrm{T}-804 \mathrm{~s}$ \\
\hline 14. NW Kanab, UT & $\mathrm{T}-758 \mathrm{j}$ & - & $\mathrm{T}-758 \mathrm{~s}$ \\
\hline 15. Leamington, UT & $\mathrm{T}-849 \mathrm{j}$ & - & $\mathrm{T}-848 \mathrm{~s}$ \\
\hline 16. Nephi, UT & $\mathrm{T}-851 \mathrm{j}$ & - & $\mathrm{T}-851 \mathrm{~s}$ \\
\hline \multicolumn{4}{|l|}{3 seed morphs per site } \\
\hline 17. Buena Vista, CO & $\mathrm{T}-465 \mathrm{j}$ & $\mathrm{T}-464 \mathrm{~g}$ & $\mathrm{~T}-465 \mathrm{~s}$ \\
\hline 18. Star Lake, NM & T-593j & $\mathrm{T}-593 \mathrm{~g}$ & $\mathrm{~T}-593 \mathrm{~s}$ \\
\hline
\end{tabular}

morph as Nezpar and Rimrock, did not cluster near one another either (Fig. 3).

Seeds from each collection site were separated into seed morphs in the laboratory, and each seed morph was increased in a field block of up to 49 individuals.

Seeds that were bulked within each field block were placed on moist blotter paper in plastic boxes with fitted lids. The boxes were prechilled at $5^{\circ} \mathrm{C}$ for 3 weeks before germination at $15^{\circ} \mathrm{C}$ in the dark. Germinated seedlings were transplanted into a steam-sterilized $75 \%$ sand / $25 \%$ peat moss v:v mixture and were grown in the greenhouse until DNA was harvested. Young leaves were collected and placed on ice for 0-3 hours prior to DNA isolation. For each accession, DNA from 2 individuals was analyzed separately.

DNA was isolated from fresh leaves by a modified CTAB extraction method (Lassner et al. 1989, Williams et al. 1993). We used the 20 primers in Operon RAPD 10mer Kit A (Qiagen, Alameda, CA). DNA was amplified in 25 $\mu \mathrm{L}$ reactions containing $10 \mathrm{mM}$ Tris- $\mathrm{HCl}(\mathrm{pH}$ 8.3), $10 \mathrm{mM} \mathrm{KCl}, 0.2 \mathrm{mM}$ each dNTP, $3 \mathrm{mM}$ $\mathrm{MgCl}_{2}, 0.8-01.2 \mu \mathrm{M}$ primer (OPAA series, OperonTech., Alameda, CA), $0.08 \mathrm{U} \cdot \mu \mathrm{L}^{-1} \mathrm{Taq}$ DNA polymerase (Stoeffel fragment, PerkinElmer, Branchberg, NJ), and $20 \mathrm{ng} \cdot \mu \mathrm{L}^{-1}$ template DNA. After being heated to $100^{\circ} \mathrm{C}$ for 2 minutes, the samples were subjected to
40 amplification cycles $\left(1\right.$ minute at $93^{\circ} \mathrm{C}, 1$ minute at $35^{\circ} \mathrm{C}, 2$ minutes at $71^{\circ} \mathrm{C}$ ) using a Perkin-Elmer 9600 GeneAmp PCR System. RAPD products were separated electrophoretically on $2 \%$ agarose gels run in $45 \mathrm{mM}$ Trisborate, $1 \mathrm{mM}$ EDTA containing $0.4 \mu \mathrm{m} \cdot \mathrm{mL}^{-1}$ ethidium bromide. For each primer pair, we performed a simultaneous PCR amplification of DNA from 2 individual plants for each of the 29 accessions and then fractionated the 58 PCR products on the same agarose gel (run 1). The presence or absence of bands was scored from photographs of the stained gels. To test overall repeatability of RAPD analyses, 12 DNA samples (6 accessions) were replicated on a 2nd day for 2 primer pairs (run 2) to assess variation from experimental error.

The proportion of shared bands $(\mathrm{F})$ for all pairs of 29 accessions was calculated as $2 \mathrm{a} /(2 \mathrm{a}$ $+b+c)$, where $a=$ the number of shared bands, $b=$ the number of bands present in the 1st accession but not the $2 \mathrm{nd}$, and c $=$ the number of bands present in the 2 nd accession but not the 1st (Nei and Li 1979). Genetic analysis was performed based on corresponding estimates of genetic distance ( $1-\mathrm{F})$ using PAUP* version 4.0b10 (Sinauer Associates, Inc., Sunderland, MA). Bootstrap values were calculated from 1000 replicates. TREEVIEW (Page 1996) was used to graph the dendrogram. A geographical distance matrix for the 


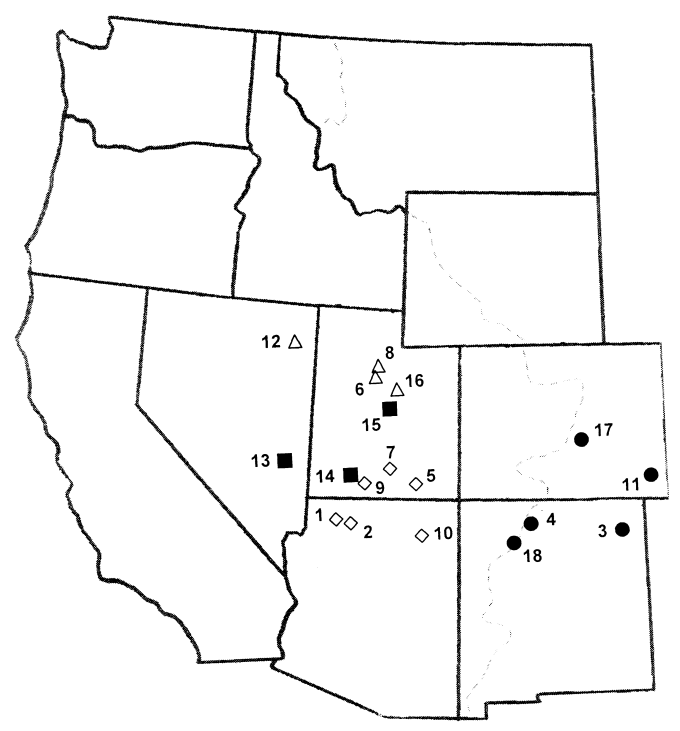

Fig. 2. Locations of 18 jumbo accessions (1-18; $\triangle=$ northeastern Great Basin, $\delta=$ southern Colorado Plateau, $\mathbf{\square}=$ intermediate, and $\mathbf{0}=$ eastern jumbo clusters) and 11 non-jumbo accessions from 9 sies (10-18)

29 Indian ricegrass accessions was assembled to assess the relationship between geographical distance and genetic distance for all accessions and for several subsets of accessions. Mantel's (1967) test was used to judge the statistical significance of these correlations using NTSYS (Exeter Software, Setauket, NY).

\section{Results And Discussion}

We scored a total of 118 RAPD fragments, 102 of which were polymorphic across the 29 Indian ricegrass accessions. The number of fragments per accession averaged 59.1 (range 51-70), and the proportion of shared fragments $(\mathrm{F})$ between 2 accessions ( $\mathrm{Nei}$ and $\mathrm{Li}$ 1979) averaged 0.70 (range 0.57-0.96; Table 2 ). The modest range in fragments per accession indicates that the level of genomic complexity within the study is relatively homogeneous. In other words, there does not appear to be major variation due to such factors as multiple ploidy levels, heterozygosity, or spurious RAPD amplification.

We observed only minor differences in banding patterns between runs 1 and 2 . On average, approximately $96 \%$ of the bands were shared (repeated) between replicated DNA samples. These minor differences appeared to be related to the efficiency of PCR and DNA staining in the gel; that is, clear but faint bands that were observed in 1 run were not always visible in the other run. Our inability to consistently detect the faint bands may have been related to our using photographs of the gels for scoring rather than electronic images. Importantly, DNA isolated from the 2 different plants of each accession always produced identical banding patterns within a run. Thus, the data themselves directly demonstrate a high degree of reliability within the experimental provisions of the study.

\section{Genetic Similarity of Sympatric Seed Morphs}

Intercalation of jumbo and non-jumbo seed morphs is common in the dendrogram (Fig. 3), suggesting that seed morph has no legitimate taxonomic status. Of the 118 markers, none was consistently present for 1 morph and consistently absent for another. Perhaps seed morph is controlled by 1 or a few major genes. This hypothesis may be tested by analyzing segregation ratios of seed morphs in $\mathrm{F}_{2}$ progeny of biparental crosses between seed morphs.

Our results indicate that sympatric seed morphs are mostly genetically dissimilar. Sympatric seed morphs never clustered together in 13 comparisons ( 7 from 7 dimorphic sites and 6 from 2 trimorphic sites), even at an extremely liberal bootstrap value of $50 \%$. In fact, for 10 of 13 sympatric comparisons, the 2 seed morphs clustered apart with a bootstrap value $\geq 78 \%$ (Fig. 3). The 3 less clearly disassociated pairs were from Montello, Nevada (T-26s, T-27j), Nephi, Utah (T-85ls, T-85lj), and Star Lake, New Mexico (T-593s, T-593g). We also tested whether genetic similarity among sympatric seed morphs (13 comparisons) is greater than among nonsympatric seed morphs (177 comparisons). The mean proportion of shared bands $(F)$ was $0.70 \pm 0.03$ (means are accompanied by a $95 \%$ confidence interval) for pairs of sympatric seed morphs and $0.68 \pm 0.01$ for pairs of nonsympatric seed morphs. Thus, sympatric morphs were no more similar than nonsympatric morphs.

If outcrossing rates between morphs were high, one would expect that sympatric accessions would be much more similar to each other than to accessions from distant locations. In general, this was not the case. Assuming 

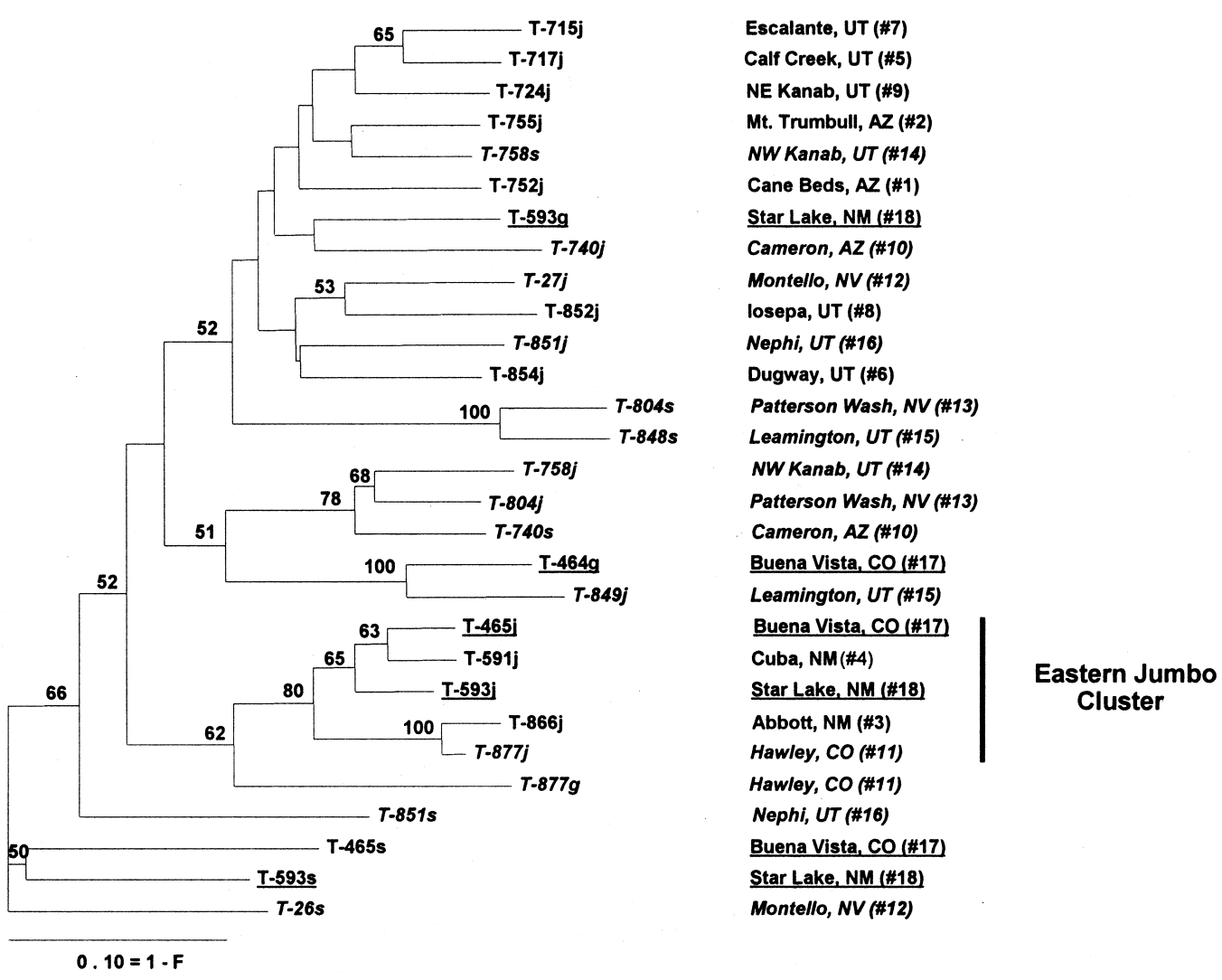

Fig. 3. Neighbor-joining dendrogram based on Nei's genetic distance for 18 jumbo $(j=$ jumbo $)$ accessions from 18 locations and 11 non-jumbo ( $\mathrm{g}=$ large, $\mathrm{s}=$ small) accessions from 9 locations (numbered at right; see Table 1, Fig. 2). Dimorphic locations are italicized, and trimorphic locations are underlined. Bootstrap values $\geq 50$ are shown.

that no genetic barriers preclude hybridization between morphs (i.e., morphs have no legitimate taxonomic status, these findings support the hypothesis of an autogamous mating system). The lack of similarity between sympatric morphs suggests not only that hybridization between seed morphs is at most minimal, but also that sympatric morphs likely have independent points of origin.

Each branch of the dendrogram (Fig. 3) represents the 2 plants of each accession, which were grown in the greenhouse from a seed lot harvested in bulk from a corresponding field block in a common garden. As stated above, no differences in RAPD profiles were seen between the 2 plants for any accession. While accessions were increased in separate field blocks, these blocks were adjacent, so an opportunity for cross-pollination was present if outcrossing were to occur. Therefore, the observation that each pair of plants possessed identical RAPD profiles is compatible with the hypothesis of a predominately autogamous mating system. Previous data have shown that self-incompatibility is absent in Indian ricegrass, as open-pollinated and bagged panicles did not differ in seed set (Jones and Nielson 1989).

The conclusion that Indian ricegrass possesses an autogamous mating system is important because of a past presumption that Indian ricegrass is self-incompatible and cross-pollinated. This has been the ostensible justification for overly strict genetic purity standards in seed certification regulations. Specifically, a minimum isolation distance between seed fields of different Indian ricegrass cultivars has been required in order to minimize pollen admixture among them, based on the presumption of the predominance of cross-pollination.

This erroneous stance has been based on data of Smith (1944), cited by Fryxell (1957), 
purporting a 94\% reduction in seed set of bagged plants relative to open-pollinated plants. This appears to be a result of an arithmetic error (Smith 1944: table 3). Reduction of seed set in bagged plants recalculated from the data presented by Smith (1944) is only 33\%. This reduction may have possibly resulted from unfavorable environmental conditions for seed set under a bag. Our data presented here and previous data (Jones and Nielson 1989) have been used to justify a relaxation of isolation standards to reflect Indian ricegrass' predominately autogamous mating system (Association of Official Seed Certifying Agencies 2002).

Despite this evidence for autogamy, several reports cited above indicate naturally occurring interspecific hybridization. Interspecific hybrids between Indian ricegrass and green needlegrass (Nassella viridula [Trin.] Barkworth) have sporadically appeared in green needlegrass breeding lines (Johnson and Rogler 1943). Conversely, we have made several observations of interspecific hybrids in Indian ricegrass breeding lines. Thus, it appears that Indian ricegrass may occasionally outcross as either a male or female parent.

\section{Genetic Variation of Seed Morphs}

Our data indicate that the correlation coefficient between geographical distance and genetic distance is much stronger for jumbo seed morphs than for non-jumbo seed morphs. Over all accessions, $r=0.39(P<0.01)$. However, for the 18 jumbo seed morphs, $r=0.48$ $(P<0.01)$ compared to $r=0.21(P<0.10)$ and $r=0.20(P>0.10)$ for the 11 non-jumbo seed morphs and the 8 small seed morphs, respectively. These results suggest that historical dispersion of the jumbo seed morph may have been simpler than that of the non-jumbo seed morphs. Perhaps the jumbo seed morphs have a common genetic origin, whereas the non-jumbo seed morphs have 2 or more origins.

Genetic variation of the relatively uncommon jumbo seed morph was comparable to that of the more typical non-jumbo seed morphs when they were compared across the same set of geographical sites. For the 9 sites in which both jumbo and non-jumbo seed morphs were present, the $95 \%$ confidence interval of average genetic distance among the 9 jumbo seed morphs $(0.29 \pm 0.03)$ overlapped the $95 \%$ con- fidence interval of the average genetic distance among the 11 non-jumbo seed morphs $(0.33 \pm 0.02)$. On the other hand, the data suggest high genetic similarity among 5 jumbo seed morphs (T-465j, T-591j, T-593j, T-866j, $\mathrm{T}-877 \mathrm{j}$ ) from the eastern portion of the sampled region (Fig. 3). These 5 jumbo accessions, the "eastern jumbo cluster," are all located at or east of the Continental Divide (Fig. 2). In contrast, the 13 jumbo seed morphs originating west of the divide in the Intermountain Region are much less genetically similar to one another. These results are best explained by a western origin of the jumbo morph and its eastward migration across the Continental Divide from a small founder population. The 5 similar eastern jumbo morphs may also have inflated the correlation between geographical and genetic distances for the jumbo morph.

Two other facts also lend credence to a western origin and eastern migration of the jumbo seed morph. First, Indian ricegrass is much more common west of the Continental Divide than east of it, particularly in the Great Basin and the Colorado Plateau. Second, the degree of seed polymorphism is greater in the southeastern Great Basin than in any of 10 other regions (Jones and Nielson 1996).

In contrast to the jumbo seed morphs of the Rocky Mountain region, the 3 large seed morphs (T-593g, T-464g, T-877g) and the 2 small seed morphs (T-465s, T-593s) from this region (Fig. 2) are not genetically similar to one another based on bootstrap values (Fig. 3). This suggests that gene flow eastward across the divide has been greater for the non-jumbo seed morphs than for the jumbo seed morph.

Besides the eastern jumbo cluster, 3 other groups of jumbo morphs have some degree of geographical similarity (Fig. 2), though none have strong statistical support (Fig. 3). Jumbo morphs T-715j (\#7 Escalante, UT), T-717j (\#5 Calf Creek, UT), T-724j (\#9 NE Kanab, UT), T-755j (\#2 Mt. Trumbull, AZ), T-752j (\# 1 Cane Beds, AZ), and T-740j (\#10 Cameron, AZ) constitute a southern Colorado Plateau group. Jumbo morphs T-27j (\#12 Montello, NV), T852j (\#8 Iosepa, UT), T-851j (\#16 Nephi, UT), and T-854j (\#6 Dugway, UT) constitute a northeastern Great Basin group. Jumbo morphs T758j (\#14 NW Kanab, UT), T-804j (\#13 Patterson Wash, NV), and T-849j (\#15 Leamington, UT) constitute a group located between 
TABLE 2. Number of RAPD fragments detected per plant in 29 Indian ricegrass accession genotypes (i.e., a $+\mathrm{b}$ or a Nei and Li 1979); and number of fragments in 1 or both accession genotypes (i.e., $a+b+c$; below diagonal). Thus, the and below-diagonal elements.

\begin{tabular}{|c|c|c|c|c|c|c|c|c|c|c|c|c|c|c|c|}
\hline & T26s & $\mathrm{T} 27 \mathrm{j}$ & $\mathrm{T} 464 \mathrm{~g}$ & $\mathrm{~T} 465 \mathrm{~s}$ & T465j & T59lj & T593s & T593g & $\mathrm{T} 593 \mathrm{j}$ & $\mathrm{T} 715 \mathrm{j}$ & $\mathrm{T} 717 \mathrm{j}$ & $\mathrm{T} 724 \mathrm{j}$ & $\mathrm{T} 740 \mathrm{j}$ & $\mathrm{T} 740 \mathrm{~s}$ & $\mathrm{~T} 752 \mathrm{j}$ \\
\hline T26s & 51 & 0.70 & 0.65 & 0.74 & 0.68 & 0.68 & 0.77 & 0.67 & 0.68 & 0.63 & 0.64 & 0.66 & 0.59 & 0.62 & 0.62 \\
\hline $\mathrm{T} 27 \mathrm{j}$ & 73 & 61 & 0.69 & 0.59 & 0.66 & 0.69 & 0.63 & 0.74 & 0.71 & 0.77 & 0.79 & 0.74 & 0.76 & 0.72 & 0.74 \\
\hline T464g & 73 & 77 & 57 & 0.63 & 0.68 & 0.67 & 0.69 & 0.70 & 0.64 & 0.66 & 0.72 & 0.68 & 0.64 & 0.77 & 0.70 \\
\hline $\mathrm{T} 465 \mathrm{~s}$ & 66 & 81 & 76 & 54 & 0.70 & 0.67 & 0.76 & 0.67 & 0.68 & 0.59 & 0.60 & 0.59 & 0.59 & 0.64 & 0.62 \\
\hline T465j & 75 & 83 & 79 & 76 & 63 & 0.94 & 0.69 & 0.68 & 0.91 & 0.65 & 0.63 & 0.66 & 0.63 & 0.68 & 0.71 \\
\hline T59lj & 75 & 81 & 80 & 78 & 67 & 63 & 0.69 & 0.68 & 0.93 & 0.69 & 0.66 & 0.71 & 0.63 & 0.66 & 0.73 \\
\hline T593s & 66 & 80 & 74 & 68 & 78 & 78 & 56 & 0.79 & 0.72 & 0.62 & 0.65 & 0.74 & 0.63 & 0.63 & 0.68 \\
\hline T593g & 76 & 78 & 78 & 78 & 83 & 83 & 72 & 63 & 0.71 & 0.74 & 0.78 & 0.79 & 0.81 & 0.73 & 0.78 \\
\hline T593j & 72 & 77 & 78 & 74 & 66 & 65 & 73 & 78 & 58 & 0.69 & 0.67 & 0.72 & 0.66 & 0.67 & 0.74 \\
\hline T715j & 77 & 75 & 79 & 81 & 84 & 81 & 81 & 78 & 78 & 61 & 0.9 & 0.86 & 0.77 & 0.69 & 0.81 \\
\hline $\mathrm{T} 717 \mathrm{j}$ & 82 & 79 & 81 & 87 & 91 & 89 & 85 & 81 & 85 & 72 & 70 & 0.88 & 0.78 & 0.70 & 0.82 \\
\hline $\mathrm{T} 724 \mathrm{j}$ & 73 & 75 & 76 & 79 & 81 & 78 & 72 & 73 & 74 & 68 & 72 & 58 & 0.76 & 0.71 & 0.83 \\
\hline $\mathrm{T} 740 \mathrm{j}$ & 77 & 74 & 78 & 79 & 83 & 83 & 78 & 72 & 78 & 73 & 78 & 72 & 58 & 0.76 & 0.81 \\
\hline T740s & 75 & 76 & 71 & 76 & 80 & 81 & 78 & 77 & 77 & 78 & 83 & 75 & 72 & 58 & 0.71 \\
\hline $\mathrm{T} 752 \mathrm{j}$ & 73 & 73 & 73 & 75 & 76 & 75 & 73 & 72 & 71 & 69 & 74 & 66 & 67 & 73 & 55 \\
\hline $\mathrm{T} 755 \mathrm{j}$ & 74 & 73 & 79 & 78 & 81 & 81 & 76 & 74 & 75 & 69 & 77 & 69 & 67 & 75 & 66 \\
\hline $\mathrm{T} 758 \mathrm{j}$ & 71 & 77 & 70 & 71 & 74 & 76 & 74 & 76 & 72 & 76 & 82 & 72 & 75 & 63 & 70 \\
\hline $\mathrm{T} 758 \mathrm{~s}$ & 75 & 78 & 78 & 78 & 84 & 82 & 79 & 77 & 78 & 71 & 78 & 69 & 73 & 76 & 69 \\
\hline T804j & 75 & 80 & 75 & 77 & 80 & 82 & 79 & 81 & 78 & 81 & 86 & 77 & 80 & 67 & 77 \\
\hline T804s & 76 & 77 & 78 & 75 & 81 & 83 & 77 & 75 & 76 & 76 & 80 & 74 & 73 & 76 & 71 \\
\hline T848s & 73 & 76 & 79 & 76 & 83 & 83 & 77 & 78 & 79 & 77 & 82 & 74 & 74 & 78 & 72 \\
\hline T849j & 74 & 80 & 65 & 78 & 81 & 82 & 75 & 80 & 80 & 80 & 83 & 78 & 80 & 74 & 75 \\
\hline T85lj & 75 & 75 & 80 & 79 & 82 & 82 & 80 & 79 & 77 & 75 & 80 & 75 & 72 & 77 & 73 \\
\hline T851s & 68 & 80 & 78 & 75 & 81 & 81 & 75 & 81 & 79 & 80 & 85 & 77 & 78 & 78 & 75 \\
\hline T852j & 74 & 70 & 78 & 80 & 84 & 85 & 80 & 77 & 79 & 75 & 78 & 72 & 73 & 78 & 71 \\
\hline T854j & 79 & 75 & 78 & 84 & 84 & 83 & 82 & 78 & 80 & 72 & 76 & 72 & 74 & 79 & 71 \\
\hline T866j & 77 & 81 & 84 & 80 & 73 & 74 & 81 & 86 & 71 & 83 & 90 & 81 & 84 & 85 & 80 \\
\hline $\mathrm{T} 877 \mathrm{j}$ & 75 & 79 & 82 & 79 & 70 & 71 & 79 & 84 & 68 & 83 & 90 & 80 & 83 & 83 & 77 \\
\hline T877g & 68 & 77 & 75 & 73 & 69 & 71 & 74 & 81 & 69 & 78 & 85 & 74 & 78 & 72 & 72 \\
\hline
\end{tabular}

the southern Colorado Plateau and northeastern Great Basin groups.

\section{Conclusions}

A polymorphic Indian ricegrass seed collection made at a single site may be thought of as a mixture of coexisting subpopulations. If the degree of gene flow among seed morphs is low, which would occur with a high level of autogamy, these subpopulations would maintain a high degree of genetic uniqueness. This conclusion is supported by the finding that similarity among sympatric morphs is no greater than it is among nonsympatric morphs. If the subpopulations have migrated independently, a polymorphic population may have resulted from overlapping waves of migration of seed morphs with distinct points of origin.

Genetic variation of the jumbo seed morph east of the Continental Divide is lower than to the west, as evidenced by the homogeneous eastern jumbo cluster. Indian ricegrass gene flow over the Continental Divide could be lim- ited by reduced fitness at higher elevations. Although Indian ricegrass is found at high elevations (Booth et al. 1980), it is much less common in montane areas than in lower-elevation valley floors. Furthermore, if the ecological advantage of the high-dormancy jumbo seed morph, in particular, is less pronounced at the high elevations, where precipitation is more dependable and evapotranspiration is less severe, then this could also limit dispersal across the Continental Divide. Alternatively, migration across the divide may be related to the inability to compete with a better-adapted genotype already present. At any rate, this apparent migration bottleneck for the jumbo seed morph did not appear to so stringently restrict eastward migration of the non-jumbo seed morphs.

Seed-size polymorphism in Indian ricegrass is an important mechanism providing genetic variation within local sites as well as across geographic space. While many restorationists have emphasized the importance of plant materials of local origin, these data suggest 
$+\mathrm{c}$; diagonal); proportion of shared fragments (i.e., $\mathrm{F}=2 \mathrm{a} /[2 \mathrm{a}+\mathrm{b}+\mathrm{c}]$ ) between accession genotypes (above diagonal; overall RAPD profiles and the proportion of shared amplicons (above-diagonal elements) can be inferred from the diagonal

\begin{tabular}{|c|c|c|c|c|c|c|c|c|c|c|c|c|c|c|}
\hline $\mathrm{T} 755 \mathrm{j}$ & $\mathrm{T} 758 \mathrm{j}$ & $\mathrm{T} 758 \mathrm{~s}$ & $\mathrm{~T} 804 \mathrm{j}$ & $\mathrm{T} 804 \mathrm{~s}$ & $\mathrm{~T} 848 \mathrm{~s}$ & T849j & T85lj & T851s & $\mathrm{T} 852 \mathrm{j}$ & $\mathrm{T} 854 \mathrm{j}$ & T866j & $\mathrm{T} 877 \mathrm{j}$ & $\mathrm{T} 877 \mathrm{~g}$ & \\
\hline 0.65 & 0.63 & 0.68 & 0.67 & 0.57 & 0.64 & 0.64 & 0.66 & 0.76 & 0.65 & 0.61 & 0.66 & 0.68 & 0.69 & $\mathrm{~T} 26 \mathrm{~s}$ \\
\hline 0.78 & 0.65 & 0.74 & 0.70 & 0.67 & 0.70 & 0.66 & 0.77 & 0.67 & 0.83 & 0.79 & 0.70 & 0.73 & 0.65 & $\mathrm{~T} 27 \mathrm{j}$ \\
\hline 0.64 & 0.73 & 0.70 & 0.74 & 0.61 & 0.60 & 0.87 & 0.64 & 0.66 & 0.66 & 0.70 & 0.61 & 0.63 & 0.64 & $\mathrm{~T} 464 \mathrm{~g}$ \\
\hline 0.62 & 0.67 & 0.67 & 0.67 & 0.62 & 0.62 & 0.61 & 0.63 & 0.67 & 0.58 & 0.56 & 0.64 & 0.65 & 0.64 & $\mathrm{~T} 465 \mathrm{~s}$ \\
\hline 0.67 & 0.72 & 0.67 & 0.72 & 0.63 & 0.61 & 0.66 & 0.68 & 0.67 & 0.62 & 0.67 & 0.85 & 0.89 & 0.81 & $\mathrm{~T} 465 \mathrm{j}$ \\
\hline 0.67 & 0.69 & 0.70 & 0.69 & 0.59 & 0.61 & 0.64 & 0.68 & 0.67 & 0.61 & 0.68 & 0.83 & 0.87 & 0.78 & $\mathrm{~T} 59 \mathrm{lj}$ \\
\hline 0.68 & 0.64 & 0.67 & 0.66 & 0.61 & 0.63 & 0.68 & 0.63 & 0.70 & 0.61 & 0.62 & 0.65 & 0.67 & 0.64 & $\mathrm{~T} 593 \mathrm{~s}$ \\
\hline 0.79 & 0.69 & 0.78 & 0.70 & 0.73 & 0.69 & 0.68 & 0.73 & 0.67 & 0.74 & 0.76 & 0.65 & 0.67 & 0.60 & T593g \\
\hline 0.72 & 0.70 & 0.71 & 0.70 & 0.65 & 0.61 & 0.62 & 0.71 & 0.65 & 0.65 & 0.68 & 0.84 & 0.88 & 0.76 & $\mathrm{~T} 593 \mathrm{j}$ \\
\hline 0.85 & 0.67 & 0.85 & 0.68 & 0.69 & 0.68 & 0.66 & 0.77 & 0.67 & 0.75 & 0.84 & 0.67 & 0.66 & 0.63 & $\mathrm{~T} 715 \mathrm{j}$ \\
\hline 0.81 & 0.67 & 0.83 & 0.70 & 0.72 & 0.70 & 0.70 & 0.78 & 0.68 & 0.79 & 0.86 & 0.66 & 0.65 & 0.62 & $\mathrm{~T} 717 \mathrm{j}$ \\
\hline 0.82 & 0.70 & 0.86 & 0.72 & 0.69 & 0.70 & 0.66 & 0.74 & 0.68 & 0.77 & 0.81 & 0.67 & 0.68 & 0.67 & $\mathrm{~T} 724 \mathrm{j}$ \\
\hline 0.85 & 0.65 & 0.79 & 0.67 & 0.71 & 0.70 & 0.62 & 0.79 & 0.67 & 0.75 & 0.78 & 0.62 & 0.63 & 0.59 & $\mathrm{~T} 740 \mathrm{j}$ \\
\hline 0.72 & 0.86 & 0.74 & 0.88 & 0.65 & 0.63 & 0.72 & 0.71 & 0.67 & 0.67 & 0.69 & 0.61 & 0.63 & 0.70 & $\mathrm{~T} 740 \mathrm{~s}$ \\
\hline 0.84 & 0.70 & 0.83 & 0.68 & 0.71 & 0.70 & 0.67 & 0.74 & 0.68 & 0.75 & 0.8 & 0.66 & 0.69 & 0.67 & $\mathrm{~T} 752 \mathrm{j}$ \\
\hline 59 & 0.68 & 0.89 & 0.69 & 0.75 & 0.75 & 0.67 & 0.78 & 0.71 & 0.76 & 0.8 & 0.65 & 0.67 & 0.63 & $\mathrm{~T} 755 \mathrm{j}$ \\
\hline 74 & 53 & 0.71 & 0.89 & 0.65 & 0.61 & 0.70 & 0.67 & 0.61 & 0.63 & 0.67 & 0.63 & 0.66 & 0.77 & $\mathrm{~T} 758 \mathrm{j}$ \\
\hline 68 & 75 & 63 & 0.72 & 0.69 & 0.69 & 0.69 & 0.77 & 0.70 & 0.79 & 0.84 & 0.65 & 0.67 & 0.62 & $\mathrm{~T} 758 \mathrm{~s}$ \\
\hline 79 & 64 & 80 & 62 & 0.67 & 0.61 & 0.72 & 0.68 & 0.66 & 0.66 & 0.7 & 0.65 & 0.66 & 0.77 & $\mathrm{~T} 804 \mathrm{j}$ \\
\hline 71 & 73 & 77 & 78 & 55 & 0.90 & 0.62 & 0.69 & 0.63 & 0.72 & 0.68 & 0.62 & 0.63 & 0.57 & $\mathrm{~T} 804 \mathrm{~s}$ \\
\hline 72 & 76 & 78 & 82 & 61 & 56 & 0.60 & 0.68 & 0.71 & 0.73 & 0.69 & 0.63 & 0.66 & 0.57 & $\mathrm{~T} 848 \mathrm{~s}$ \\
\hline 78 & 72 & 79 & 77 & 78 & 80 & 58 & 0.66 & 0.63 & 0.65 & 0.71 & 0.59 & 0.61 & 0.59 & T859j \\
\hline 73 & 76 & 76 & 81 & 76 & 77 & 80 & 61 & 0.70 & 0.82 & 0.82 & 0.74 & 0.71 & 0.70 & $\mathrm{~T} 85 \mathrm{lj}$ \\
\hline 76 & 78 & 79 & 81 & 78 & 74 & 80 & 78 & 59 & 0.73 & 0.69 & 0.65 & 0.69 & 0.63 & T85ls \\
\hline 73 & 77 & 74 & 81 & 73 & 73 & 79 & 71 & 75 & 59 & 0.84 & 0.67 & 0.67 & 0.61 & $\mathrm{~T} 852 \mathrm{j}$ \\
\hline 73 & 77 & 73 & 81 & 78 & 78 & 78 & 73 & 80 & 71 & 63 & 0.71 & 0.70 & 0.64 & $\mathrm{~T} 854 \mathrm{j}$ \\
\hline 83 & 80 & 86 & 85 & 82 & 82 & 86 & 79 & 83 & 82 & 82 & 64 & 0.96 & 0.74 & T866j \\
\hline 81 & 78 & 84 & 84 & 81 & 80 & 84 & 80 & 80 & 81 & 82 & 66 & 63 & 0.76 & $\mathrm{~T} 877 \mathrm{j}$ \\
\hline 77 & 65 & 80 & 71 & 77 & 78 & 78 & 74 & 77 & 78 & 79 & 74 & 72 & 53 & $\mathrm{~T} 877 \mathrm{~g}$ \\
\hline
\end{tabular}

that nature has accommodated and maintained Indian ricegrass material that has emigrated from distant locales, resulting in coexistence with previous immigrants. Thus, for reintroduction of this species to a restoration site, a polymorphic seeding of a more germinable seed morph and a less germinable seed morph may be as or more genetically appropriate, and ecologically appropriate, than a monomorphic seeding.

Outbreeding depression, defined as a "reduction in mean population fitness resulting from hybridization between genetically distinct individuals or populations of the same species" is sometimes invoked as a reason for not introducing nonlocal material to a restoration site (Hufford and Mazer 2003). These authors term such genetically incompatible populations as "epitypes." However, because of Indian ricegrass' low outcrossing rate and the common occurrence of polymorphism in natural populations, concerns over possible maladaptation resulting from outbreeding depression in this species are probably unjustified.

\section{Literature Cited}

[aOsCa] Association of Official Seed Certifying AgEnCIEs. 2002. 84th annual report. Grass Committee, Association of Official Seed Certifying Agencies, Moline, IL. 119 pp.

2005. Operational procedures, crop standards and service programs publication (genetic and crop standards) [cited on 10 May 2005]. Available from: http://www.aosca.org/2004\%20Yellow\%20Book, \%20pdf.pdf

Booth, D.T., C.G. Howard, and C.E. Mowry. 1980.'Nezpar' Indian ricegrass: description, justification for release, and recommendations for use. Rangelands 2:53-54.

FEndaLL, R.K. 1966. An investigation into the site and cause of seed dormancy of Stipa viridula and Oryzopsis hymenoides [abstract]. Doctoral dissertation, North Dakota State University, Fargo. Dissertation Abstracts 26:3569-3570.

FryXeLL, P.A. 1957. Mode of reproduction of higher plants. Botanical Review 23:135-233.

Hufford, K.M., AND S.J. Mazer. 2003. Plant ecotypes: genetic differentiation in the age of ecological restoration. Trends in Ecology and Evolution 18:147-155.

Huntamer, M.Z. 1934. Dormancy and delayed germination of Oryzopsis hymenoides. Master's thesis, State College of Washington, Pullman. 
Johnson, B.L. 1945. Natural hybrids between Oryzopsis hymenoides and several species of Stipa. American Journal of Botany 32:599-608.

1960. Natural hybrids between Oryzopsis and

Stipa. I. Oryzopsis hymenoides X Stipa speciosa. American Journal of Botany 47:736-742.

1962. Natural hybrids between Oryzopsis and Stipa. II. Oryzopsis hymenoides X Stipa nevadensis. American Journal of Botany 49:540-546.

. 1963. Natural hybrids between Oryzopsis and Stipa. III. Oryzopsis hymenoides X Stipa pinetorum. American Journal of Botany 228-234.

Johnson, B.L., AND G.A. RogLer. 1943. A cytotaxonomic study of an intergeneric hybrid between Oryzopsis hymenoides and Stipa viridula. American Journal of Botany 30:49-56.

Jones, T.A. 1990. A viewpoint on Indian ricegrass: its present status and future prospects. Journal of Range Management 43:416-420.

2005. Native seeds in commerce. Native Plants Journal 6:286-293.

Jones, T.A., AND D.C. Nielson. 1989. Self-compatibility in 'Paloma' Indian ricegrass. Journal of Range Management 42:187-190.

1996. Seed size and shape and lemma color polymorphism in Oryzopsis hymenoides (Roem. \& Schult.) Ricker. Pages 272-273 in N.E. West, editor, Proc. V International Rangeland Congress, Salt Lake City, UT. 23-28 July 1995.

. 1999. Intrapopulation genetic variation for seed dormancy in Indian ricegrass. Journal of Range Management 52:646-650.

Larson, S.R., E. Cartier, C.L. McCracken, and D. Dyer, 2001. Mode of reproduction and amplified fragment length polymorphism variation in purple needlegrass (Nassella pulchra): utilization of natural germplasm sources. Molecular Ecology 10:1165-1178.

Lassner, M.W., P. Peterson, And J.I. Yoder. 1989. Simultaneous amplification of multiple DNA fragments by polymerase chain reaction in the analysis of transgenic plants and their progeny. Plant Molecular Biology Reporter 7:116-128.

Mantel, N.A. 1967. The detection of disease clustering and a generalized regression approach. Cancer Research 27:209-220.
NEI, M., AND W.H. Li. 1979. Mathematical model for studying genetic variation in terms of restriction endonucleases. Proceedings National Academy of Sciences USA 76:5269-5273.

Nielson, E.L., AND G.A. Rogler. 1952. An amphiploid of X Stiporyzopsis. American Journal of Botany 39:343348.

PAge, R.D. 1996. TREEVIEW: An application to display phylogenetic trees on personal computers. Computer Applications in the Biological Sciences 12: 357-358.

Sмith, D.C. 1944. Pollination and seed formation in grasses. Journal of Agricultural Research 68:79-95.

StODDART, L.A., AND J.J. WiLKINSON. 1938. Inducing germination in Oryzopsis hymenoides for range reseeding. Journal of the American Society of Agronomy 30:763-768.

Toole, V.K. 1940. The germination of seed of Oryzopsis hymenoides. Journal of the American Society of Agronomy 32:33-41.

Weber, W.A. 1957. A new intergeneric natural hybrid involving Oryzopsis and Stipa (Gramineae). Rhodora 59:273-277.

Williams, J.G.K., M.K. Hanafey, J.A. Rafalski, and S.V. TINGEY. 1993. Genetic analysis using random amplified polymorphic DNA markers. Methods in Enzymology 218:704-740.

Young, J.A., AND R.A. Evans. 1984. Germination of seeds of 'Paloma' and 'Nezpar' Indian ricegrass. Journal of Range Management 37:19-21.

Zemetra, R.S. 1979. Reducing seed dormancy in Indian ricegrass, Oryzopsis hymenoides. Master's thesis, Colorado State University, Fort Collins.

Zemetra, R.S., and R.L. Cuany. 1984. Variation in lemma thickness in Indian ricegrass: implications for dormancy, scarification, and breeding. Crop Science 24:1082-1084

Received 21 October 2005 Accepted 7 September 2006 